\title{
COVID-19 Crises: Global Economic Shocks vs Pakistan Economic Shocks
}

\author{
Naveeda K. Katper ${ }^{1}$, Muhammad Nawaz Tunio, ${ }^{2,}$, Niaz Hussain ${ }^{3}$, Attaullah Junejo ${ }^{4}$, Faheem Gul Gilal ${ }^{5}$ \\ ${ }^{1}$ Institute of Business Administration, University of Sindh, Jamshoro, 76080, Pakistan \\ ${ }^{2}$ Doctoral Track Entrepreneurship, Innovation and Economic Development, Alpen Adria University Klagenfurt, Klagenfurt, 9020 , \\ Austria \\ ${ }^{3}$ Department of Syriah and Management, University of Malaya, Kuala Lumpur, 50603, Malaysia
}

${ }^{4}$ Office of Accountant General Sindh, Karachi, 75400, Pakistan

${ }^{5}$ Department of Business Administration, Sukkur IBA University, Sukkur, 65200, Pakistan

\begin{tabular}{l} 
A R T I C L E I N F O \\
\hline Article history: \\
Received: 01 June, 2020 \\
Accepted: 23 July, 2020 \\
Online: 25 August, 2020
\end{tabular}

Keywords:

Contagious virus

COVID-19

Economic Shocks

Socio-psychology

Behavioral economics

\begin{abstract}
A B S T R A C T
This paper documents, information about the current outbreak of Corona virus and its multidimensional effects witnessed worldwide. The objective of the study is to disseminate information to policymakers, government and the general public, to facilitate the efforts for fighting against the contagious virus and aims to contribute to the economic and social welfare. Though the data changes rapidly by every passing minute, yet the current scenario may be analyzed to evaluate the present situation for a fruitful outcome. Hence, the discussion may be useful for all the stakeholders (government, policymakers and the public) for their reference. Various studies previously observed that widespread contagious diseases have a severe impact on the economy. It is observed that the faster and wider the outbreak of disease, the higher and severer the influence on the economies. The economies face shrinkage of income, revenue, earnings, while health expenditure increases for hospitals, medical kits, ventilators, uniforms, masks, gloves, medicines and other medical equipment. Therefore, it has a two-pronged adversely hitting effect on economies to manage the imbalance in the budget and fiscal matters. Another unfortunate situation is when the high populated country is poor too. The world has realized the effects of the different contagious viruses in the different times in history. Nevertheless, the virulence and the severity of the COVID-19 is far greater than the previous viral breakouts. We, in this research attempt to highlight the multidimensional effects of COVID-19 and create some possibilities how to deal and fight with this cruel and invisible enemy.
\end{abstract}

\section{Introduction}

Where there are many advantages of globalization, there are disadvantages attributed to it, as well. What we are facing currently in the shape of contagious viral breakout worldwide is one such example. Therefore, one should not think that the disaster that happens in one country would not affect the other. Everything is affected because of the social interaction and shared economies around the globe. Education, skills, tourism, business and human resource mobilization are major factors which create a cause for connecting the people and making the world a global village.

*Corresponding Author: Muhammad Nawaz Tunio. Mozartstrasse 61, Klagenfurt 9020, Austria.m1tunio@edu.aau.at Cell No. 004368860041579
What we are facing currently in the shape of contagious viral breakout worldwide is one such example. Therefore, one should not think that the disaster that happens in one country would not affect the other. Everything is affected because of the social interaction and shared economies around the globe. Education, skills, tourism, business and human resource mobilization are major factors which create a cause for connecting the people and making the world a global village.

In this connection whenever the good comes to one country, it reaches to other also by imports, social attitudes or demonstration effect. Accordingly, when evil occurs in one country, the same comes to the rest of the world. Today we the habitants of this global village are facing the same evil occurrence in the shape of 


\section{N.K. Katper et al. / Advances in Science, Technology and Engineering Systems Journal Vol. 5, No. 4, 645-654 (2020)}

the novel coronavirus. It is only due to the interconnection of the countries of the whole world called global village. This strengthens the concept that everything has its pros and cons on its side.

Similarly, where the globalization has shared knowledge, expertise, technical skills and productive output of resources among countries, it shares bad events there too, which weakens the ability of workforce as being witnessed today as an aftermath of COVID-19 outbreak. Resultantly, cause deaths and morbidity in human resource globally. According to [1] "In a strongly connected and integrated world, the impacts of the disease beyond mortality (those who die) and morbidity (those who are unable to work for some time) have become apparent since the outbreak". They further elaborate that due to the novel coronavirus, a panic is created between business and consumers. That has created market anomalies and slanted consumption patterns. International financial markets and global stock indices have plunged in the response of changing world conditions.

Moreover, the intensity of loss increases when the country is underdeveloped like Pakistan. The socio-economic effects of COVID-19 are dispersed with greater force across developing countries and their emerging markets. Such increasing effect has directly hit their income adversely. The loss of employment creates declining GDP, national income GNP and per capita income leading to the rise in poverty. As in 2019 more than $25 \%$ of the population lived below the poverty line and more than $29.5 \%$ of the population considered poor and depends on agriculture. Such a component of the population is expected to reach $40 \%$, according to the World Bank report (see Figure 1). The graph shows the Poverty Headcount Ratio since 2001 to $2020 \mathrm{f}$ (forecast). "Poverty Headcount Ratio":

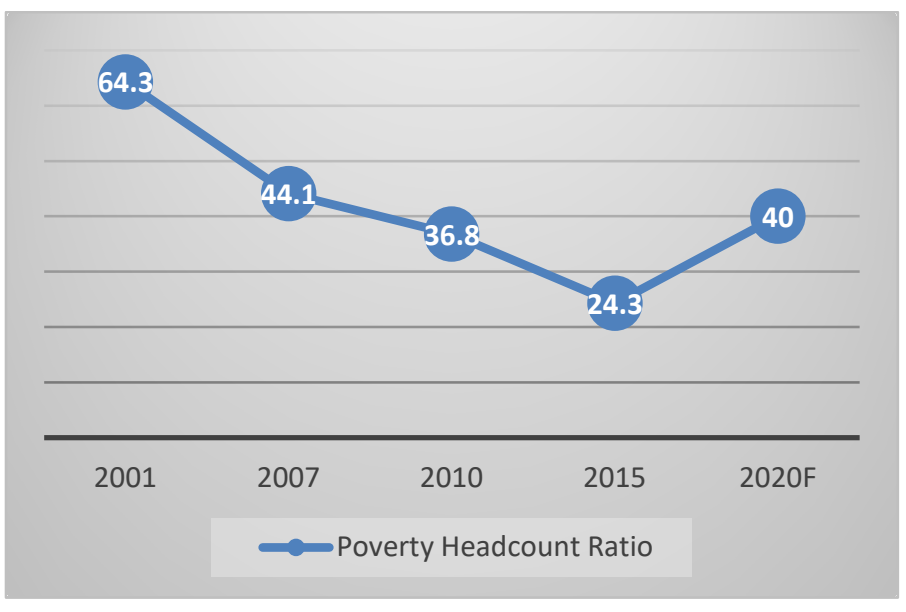

Figure.1 Poverty headcount ratio (Source: World Bank)

Pakistan's per capita income is already lower. The average per capita income is estimated at 1250 USD. Such a lower income rate cannot even fulfil the basic needs of people. Higher unemployment rates around six per cent, according to "Trading Economics, global macro models and analysts expectations" 1 . Most of the labor force comprising of daily wage and temporary employment under the informal sector, worried about their bread and butter. The industry is not as strong as in developed countries.
Pakistan relies heavily on the imports for most technical products, automobiles, machinery and oil. Similarly, exports are more important for these developing countries whose foreign exchange is not at a satisfactory level, rather indebted to international institutions heavily and chronically. In this backdrop, the outbreak of COVID-19 is a big disaster for Pakistan threatening all spheres including its crippling economy.

Here the research question arises, due to COVID-19 what aspects of the economy of the world and Pakistan, in particular, are affected? To what extent the world is experiencing psychological and socioeconomic shocks? And how far their impact would be seen?

Therefore, our objective is to evaluate and analyze the effects of this epidemic COVID-19 on the world and Pakistan economy. To what extent, particularly psychological, social and economic hits the globe is facing currently. In this study, we try to focus on the emerging threats jeopardies and vulnerabilities in the world economy that may be considered. The economic costs of viral outbreaks were different in the past as compared with the current worldwide spread of viral disease. The economic cost is directly proportionate with the rise of the virus; rather the cost has a multiplying impact for the least developed economies. Deaths and illness or morbidity further create chaos in multi spheres. It also sprouts the disability and uncertainty at the workplace in future.

The paper is structured further as below; section 2 provides some previous studies on the pandemic. Section 3 briefs the method to articulate the study while section 4 discusses and analyses the different economic shocks worldwide and in Pakistan by highlighting its different aspects. Section 5 concludes the paper and section 6 suggests some recommendations on the issue.

\section{Previous studies on pandemics}

The economy cannot be separated from the health of the population as the human resource is the major factor of production. Therefore, the health of people and economies go together either grow/flourish or weaken/collapse. A lot of research is conducted on the issue that has found that the health of the population is closely concerned with economic welfare and economic growth [2-9]. Other studies on SARS, including [10] for Taiwan, [11] for China and [12] for Hong Kong also elaborate the worse situation of the affected regions. These studies directly or indirectly can be connected to this current issue, however the effects higher than the historical contagious diseases. We can also comprehend that the health of people and the health of the economy are directly connected.

In the $20^{\text {th }}$ century, the historical breakouts of epidemics that world witnessed are: "Spanish Influenza of 1918, Asian flu of 1957 and the Hong Kong flu of 1968. In the $21^{\text {st }}$ century, outbreaks are N1H1 in 2009 ('bird flu'), Severe Acute Respiratory Syndrome (SARS) in 2002, Middle East Respiratory Syndrome (MERS) in 2012, and Ebola which peaked in 2013-14" [13]. All these pandemics spread panic in the regions when they broke out and infected population at large scale by health and economic depressions. For example, in 2003 by the breakout of SARS, the economic problems increased. There was a huge reduction in the demand or consumption and the cost of operating a business which increased the uncertainties and risk premium. The spread

${ }^{1}$ https://tradingeconomics.com/pakistan/unemployment-rate www.astesj.com 
of disease crossed borders, according to the interaction of the host country's exposure and predisposition to the disease. Similarly, [14], describes that AIDS/HIV affects the economy. Government, business and households suffer through changing labor supply, labor efficiency, growing cost of business and confining investment in training of staff by firms, increased health care expenditure by supporting disabled people and orphan children due to AIDS in public sectors.

The researchers elaborate that despite a low level of health damage, mortality rate and the small number of deaths the world suffered a lot in terms of economic loss. The global cost witnessed that it is not only specific to the countries affected adversely [15]. Conversely, the impact of COVID-19 is far more than the formerly experienced contagions because this is not the story of a few countries, rather the disaster of the whole world consisting around 200 countries. This epidemic impact on the health of people and the economy is much more than World War I and World War II. These wars did not infect 200 countries all around. The unexpected and sudden blow-out of coronavirus has put the entire world into the shock. According to [15] "The fear of 191819 Spanish influenza, the deadliest plague in history, with its extreme severity and gravity of clinical symptoms, is still present in the research and general community". Likewise, at the start of breakout people think that COVID-19 has the same level of fear as the other former contagious diseases. On the contrary, the COVID-19 has infected at greater extent by multi spheres all over the world. Plenty of research is available about previously highly infectious observed diseases of epidemic for which no vaccine prepared yet. All that literature providing experience from these aforementioned epidemics can be informative to some extent how to think and deal regarding COVID-19 for implications [16].

However, this time the invisible enemy COVID-19 has played far beyond the previous epidemics did. According to CEPR Press, 2020, the number of people affected by the COVID19 is much greater than the SARS cases. Hence, due to the fear of novel coronavirus, countries have started lockdown. Lockdown is creating a gap in the world level economy. The contagious virus is going to be affected so badly that countries went for lockdown and curfew.

To see the global situation, John Cochrane in the chapter of eBook indicates some bold queries about lockdown mechanism. That there will not be any disaster if a short pause is given to economize for a certain period for the sake of public health and socioeconomic prosperity. For this, there should be a systemic way and constructive approach in implementing it properly and completely. The researcher displays worry about huge financial issues even for firms' disbursements or payments of debts, mortgage, salaries, wages, rents, utilities. Subsequently, when the business shuts during lockdown under demand shock, how can household and firms manage their fixed costs? This fear is felt and John Cochrane writes that it is possible to occur economic shocks like bankruptcies, insolvencies as well as inability to pay the bills. Lockdown situation will prolong across economic fluctuations as happened in 2001 and 2008.

The great influence of the COVID-19 on the economy has been started due to the prolonged worldwide shut down. What repercussions the world is observing the matter of attention and focus so that some way out could be found to cope with this perilous condition.

\section{Methodology}

In this study, our objective is "to evaluate and analyze the effects of this epidemic COVID-19 on the world and Pakistan economic shocks and what particular psychological, social and economic hits the globe is facing currently". Therefore the methodology we used is mostly through collecting secondary data by desk research we referred published reports and statistics by different sources ranging from national and international surveys, reviews and publications [17]. For that purpose, we conducted desktop research, accordingly. We also reviewed and referred to the research papers on the subject. In this study, we have analyzed the current pandemic situation and discussed its multi sphere effects on economic factors during the occurrence of the pandemic situation. We evaluated the world economic shocks as well as Pakistan economic shocks being faced by the masses.

\section{Analysis and discussion on the multi sphere, economic shocks}

\subsection{Global economic shocks}

As the first attack of COVID-19 in China, the second-largest economy behind US $1 / 3$ of world manufacturer and world's largest exporter shut down after viral breakout. According to Statista expected report 2019, China's GDP contributes to $19.24 \%$ of the global total in 2019 and $19.72 \%$ in 2020 ; the same is expecting $21.39 \%$ in 2024. Despite that China's economic effect is widely noticed and spread globally.[18], in the ebook of CEPR Press, mention that the Chinese economy showed a sluggish pattern in the $1^{\text {st }}$ quarter of 2020 . While looking at the global economic situation and economic contribution, China stands high by contribution in global GDP by $17 \%$, in world trade by $9 \%$, in global tourism by $9.3 \%$ and in global demand by $40 \%$ which leaves not a positive impression and influence to the other countries. This does not affect china only, but also the supply and demand of the rest of the country.

However, it is observed that the World GDP is condensed up to $0.75 \%$, by this the impact on world GDP growth is being around half a present point in 2020. The reason for this decline is due to the initial curtailment in the demand in China. Thus China's international trade has significantly declined by around $1.4 \%$ in the $1^{\text {st }}$ half of and $0.9 \%$ in the whole year of 2020 . China's cross border linkage is strong with other countries through commodity exporters of Japan, Korea, East and South-East Asian countries ranging from the supply chain, tourism and other travel-based services. All other countries of America, Europe, Middle East and Asia are growing seriously infected day by day. Therefore, the whole world is facing isolation and lockdown due to which all economic activities are stagnant. All together the countries affected over $70 \%$ of global GDP in terms of PPP. Thus, the big economies of the world are infected by this invisible enemy at their worst. The world's GDP trend of various countries since $2017-2020$ can be seen in the table 1.

According to [19]."Taking just the US, China, Japan, Germany, Britain, France, and Italy, they account for $60 \%$ of world supply and demand (GDP), $65 \%$ of world manufacturing, and $41 \%$ of world manufacturing exports".Due to a strong supply chain in the regional dimension, China, Japan, Korea at hardhitting and this shock of the supply chain will be extended to whole Asia. According to an estimate, the global GDP has 


\section{N.K. Katper et al. / Advances in Science, Technology and Engineering Systems Journal Vol. 5, No. 4, 645-654 (2020)}

declined by $1.75 \%$ in the latter half of 2020 , whereas it is to be declined around $1.5 \%$ in the full-year GDP growth impact in 2020. Global trade is, decreasing approximately by $3.75 \%$ in 2020 , hammering exports in all economies.

The global panic of COVID-19 has created unprecedented uncertainty to a level which caused a massive reduction in oil prices, resulted by declining of investment in China and the rest of the world. IEA further foresees the global oil demand falling by " 435,000 barrels per day when compared at the year-on-year basis. The current quarter compared with the corresponding period of last year reveals that the world has witnessed the highest shrinkage in the economy of the decade. It is expected further that the global oil demand will further touch to the low by " 365,000 barrels per day". It is said to be the worst behavior of demand since 2011. Consequently, "OPEC plus countries consider the reduction in oil production of 600,000 barrels a day as an emergency measure on the top of the 1.7 million barrels a day already pledged" [20]. This declining scenario is observed only from the direct effect of shrinkage of demand-supply side. However, the impact of the risk and future uncertainty is yet to cripple in slow the days to come.

Furthermore, the financial sector and the global stock markets have witnessed crashed down situations all over the world. Stock exchanges are experiencing a decline in market capitalization on an hourly basis. European stock indices, American stock markets witnessed worst drops since March 20, 2020. Financial crunch and stock market of developing countries would lead their economies into a hazard. Puts it: "Developing economies in East Asia and the Pacific (EAP), recovering from a trade war and struggling with a viral disease, now face the prospect of a global financial shock and recession. Given the unprecedented nature of the economic shock to each country, and the fact that it is also affecting all other countries in the region and beyond, an exceptional policy response is needed". Hence, having more than $70 \%$ of the poor population in developing countries is more vulnerable to the situation. The production has declined and so the employment level due to the shutter down and bans imposed for halting the outbreak of this pandemic. The lowgrade staff or daily wage labor is burdening the economy in two ways. From one side they are unproductive whereas from the other side the governments have to arrange their bread.

\subsection{Multidimensional hits of COVID-19}

COVID-19 has created chaos and hitting in multi spheres globally. The effect of this contagious virus is discussed below along with the decoration of the graphical presentation.

\subsection{Demographic hits}

The rampant and contagious coronavirus has created a global emergency. The demographic change has occurred dramatically. It has hit the health of people in millions across the world. The figures of infected people change quickly in minutes all over the world. The reasons are all other kinds of flu viruses do not transmit faster, the way it transmits from one person to another. Its mortality rate is $2 \%$ to $3 \%$, which is greater than other viruses.
Thus, what people have faced already is terrible. Increasing deaths or mortality rates, illness and morbidity by damaging health have created a big demographic change in the world.

According to [21] who runs preparedness efforts for NYC Health and Hospitals, said: "This particular virus seems like it is highly transmissible, I think that it is certainly plausible that 40 $70 \%$ of the world's population could become infected with coronavirus disease, but a large number of cases are (expected to be) mild."

\subsection{Economic hit:}

The novel coronavirus is witnessed as contagious economically as it is medically. The economy is suffering and gets a double hit in the following ways:

1. From one side "revenue reduction": Coronavirus affects all type of enterprises specifically service sector and small \& medium enterprises (SMEs). All forms of business organizations such as manufacturing, trade and service organizations are facing curtailment of operational activities. Millions of formal as well as informal employment and selfemployment are affected. The business loss occurred as services have been curtailed globally. Transport being limited and even restricted among countries has further slowed down global economic activities. It has further minimized the consumption of oil and other fuels. Resultantly, Oil \& petrol companies face revenue loss. The lockdowns resulted in low production, which has reduced the local and global trade. As the world economies also depend on international trade, which has dented the economies world over. Confined economic activities have resulted in revenue kerbing. For example, hotel booking cancellation, restaurants, marriage halls supermarkets, casinos, bars, pubs, saloons, and parlours shut down, limited supply chain, banned exports and imports, worldwide airline cancellation, and restricted tourism, all have affected the revenue generation and ultimately the economies of the world. Hence the loss of tax collection would also occur and the Governments would bear this burden on the exchequer. The fiscal and monetary policies, depending on government revenue collection, have witnessed major policy shifts. It ultimately shows a big economic depression for all economies.

2. From the other side "expenditure extension" For the national security purpose, huge expenditure is set for this battle to fight by purchasing expensive medical equipment in huge number. Every country is engaged in making budgets for vaccines, medicines, ventilators, isolation centres, hospitals and other medical apparatus. Addition to that spending on research and science in this particular direction to prepare apparatus, vaccines and medicines, as well as other health care expenditure, would be a severe problem for poor countries. Thus, revenue reduction and extending expenditure for poor economies is a big challenge. Because the loss of human lives and economies by COVID-19 is greater than the world witnessed before. 
Table 1: Economic situation of the world

\begin{tabular}{|c|c|c|c|c|c|c|c|}
\hline \multirow[t]{2}{*}{ Real GDP (\% change from previous years) } & \multicolumn{7}{|c|}{$\begin{array}{r}\text { (\% difference from } \\
\text { January } 2020 \text { forecasts) }\end{array}$} \\
\hline & 2017 & 2018 & 2019 & $2020 \mathrm{f}$ & $2021 \mathrm{f}$ & $2020 \mathrm{f}$ & $2021 \mathrm{f}$ \\
\hline World & 3.3 & 3.0 & 2.4 & -5.2 & 4.2 & -7.7 & 1.6 \\
\hline Advanced economies & 2.5 & 2.1 & 1.6 & -7.0 & 3.9 & -8.4 & 2.4 \\
\hline United States & 2.4 & 2.9 & 2.3 & -6.1 & 4.0 & -7.9 & 2.3 \\
\hline Euro Area & 2.5 & 1.9 & 1.2 & -9.1 & 4.5 & -10.1 & 3.2 \\
\hline Japan & 2.2 & 0.3 & 0.7 & -6.1 & 2.5 & -6.8 & 1.9 \\
\hline $\begin{array}{l}\text { Emerging market and developing } \\
\text { economies }\end{array}$ & 4.5 & 4.3 & 3.5 & -2.5 & 4.6 & -6.6 & 0.3 \\
\hline Commodity-exporting EMDEs & 2.2 & 2.1 & 1.5 & -4.8 & 3.1 & -7.4 & 0.2 \\
\hline Other EMDEs & 6.1 & 5.7 & 4.8 & -1.1 & 5.5 & -6.2 & 0.3 \\
\hline Other EMDEs excluding China & 5.4 & 4.8 & 3.2 & -3.8 & 3.5 & -7.6 & -0.8 \\
\hline East Asia and Pacific & 6.5 & 6.3 & 5.9 & 0.5 & 6.6 & -5.2 & 1.0 \\
\hline China & 6.8 & 6.6 & 6.1 & 1.0 & 6.9 & -4.9 & 1.1 \\
\hline Indonesia & 5.1 & 5.2 & 5.0 & 0.0 & 4.8 & -5.1 & -0.4 \\
\hline Thailand & 4.1 & 4.2 & 2.4 & -5.0 & 4.1 & -7.7 & 1.3 \\
\hline Europe and Central Asia & 4.1 & 3.3 & 2.2 & -4.7 & 3.6 & -7.3 & 0.7 \\
\hline Russia & 1.8 & 2.5 & 1.3 & -6.0 & 2.7 & -7.6 & 0.9 \\
\hline Turkey & 7.5 & 2.8 & 0.9 & -3.8 & 5.0 & -6.8 & 1.0 \\
\hline Poland & 4.9 & 5.3 & 4.1 & -4.2 & 2.8 & -7.8 & -0.5 \\
\hline Latin America and the Caribbean & 1.9 & 1.7 & 0.8 & -7.2 & 2.8 & -9.0 & 0.4 \\
\hline Brazil & 1.3 & 1.3 & 1.1 & -8.0 & 2.2 & -10.0 & -0.3 \\
\hline Mexico & 2.1 & 2.2 & -0.3 & -7.5 & 3.0 & -8.7 & 1.2 \\
\hline Argentina & 2.7 & -2.5 & -2.2 & -7.3 & 2.1 & -6.0 & 0.7 \\
\hline Middle East and North Africa & 1.1 & 0.9 & -0.2 & -4.2 & 2.3 & -6.6 & -0.4 \\
\hline Saudi Arabia & -0.7 & 2.4 & 0.3 & -2.8 & 2.5 & -5.7 & 0.3 \\
\hline Iran & 3.8 & -4.7 & -8.2 & -5.3 & 2.1 & -5.3 & 1.1 \\
\hline Egypt & 4.2 & 5.3 & 5.6 & 3.0 & 2.1 & -2.8 & -3.9 \\
\hline South Asia & 6.5 & 6.5 & 4.7 & -2.7 & 2.8 & -8.2 & -3.1 \\
\hline India & 7.0 & 6.1 & 4.2 & -3.2 & 3.1 & -9.0 & -3.0 \\
\hline Pakistan & 5.2 & 5.5 & 1.9 & -2.6 & -0.2 & -5.0 & -3.2 \\
\hline Bangladesh & 7.3 & 7.9 & 8.2 & 1.6 & 1.0 & -5.6 & -6.3 \\
\hline Sub-Saharan Africa & 2.6 & 2.6 & 2.2 & -2.8 & 3.1 & -5.8 & 0.0 \\
\hline Nigeria & 0.8 & 1.9 & 2.2 & -3.2 & 1.7 & -5.3 & -0.4 \\
\hline South Africa & 1.4 & 0.8 & 0.2 & -7.1 & 2.9 & -8.0 & 1.6 \\
\hline Angola & -0.1 & -2.0 & -0.9 & -4.0 & 3.1 & -5.5 & 0.7 \\
\hline \multicolumn{8}{|l|}{ Memorandum items } \\
\hline \multicolumn{8}{|l|}{ Real GDP } \\
\hline High-income countries & 2.4 & 2.2 & 1.7 & -6.8 & 3.8 & -8.3 & 2.3 \\
\hline Developing countries & 4.8 & 4.4 & 3.7 & -2.4 & 4.7 & -6.7 & 0.2 \\
\hline Low-income countries & 5.4 & 5.8 & 5.0 & 1.0 & 4.6 & -4.4 & -0.9 \\
\hline BRICS & 5.3 & 5.3 & 4.7 & -1.7 & 5.3 & -6.6 & 0.4 \\
\hline World (2010 PPP weights)* & 3.9 & 3.6 & 2.9 & -4.1 & 4.3 & -7.3 & 1.0 \\
\hline World trade volume* & 5.9 & 4.0 & 0.8 & -13.4 & 5.3 & -15.3 & 2.8 \\
\hline \multicolumn{8}{|l|}{ Commodity prices* } \\
\hline Oil prices & 23.3 & 29.4 & -10.2 & -47.9 & 18.8 & -42.5 & 16.9 \\
\hline Non-energy commodity price index & 5.5 & 1.8 & -4.2 & -5.9 & 3.0 & -6.0 & 1.3 \\
\hline
\end{tabular}




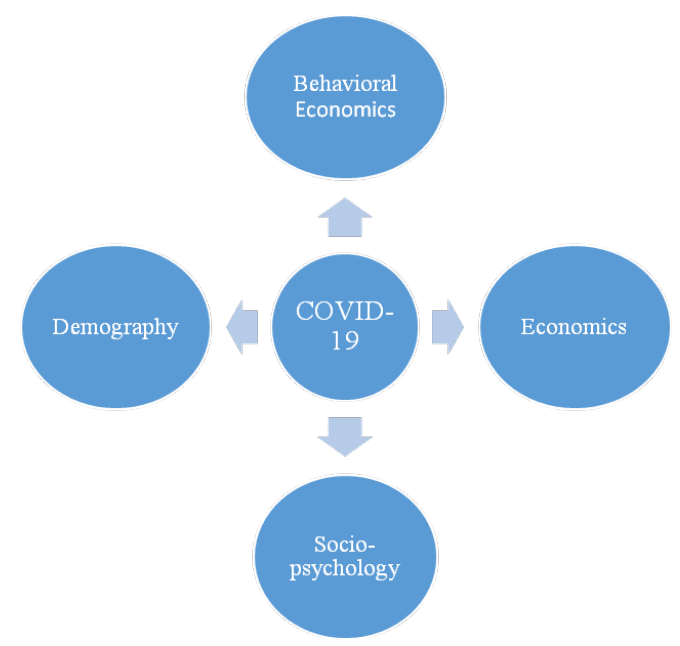

\subsection{Socio-psychological hit:}

The socio-psychological effect of coronavirus is felt greater than ever in the history of viruses' breakouts at different times in the world before. Intensifying fears of a global recession also circulate in Governments, business communities and the general public of all countries. Panic has created a deep impression on the psychology of people. There is a challenge for doctors, nurses, police and army while dealing with patients, salute to them. The uncertainty of the future and risk of lives has created a great depression all over the world. People are suffering from depression in quarantine and isolation. Indeed, such pandemics spread a lot of fear and panic so that people cannot perform at their normal level. As the same effect was noticed in 1918 on the breakout of Spanish influenza and Word Health Organization estimates a bigger number of people some more than 300 million people were suffering from stress and depression worldwide and becomes the leading cause of disability in human. Also, [22] describes that the invisible and lethal situation of virus creates not only the biological issue, but also a psychological pressure like a terrorism threat which leaves long-lasting consequences. However, due to COVID-19 in 2020, the extent of depression is far more than ever expected. [23] also opine the same by describing that a large proportion of the masses will observe the risk of pandemic whereas the risk of death will not be equal.

Due to physical and psychological distress in patients either they lose their appetite temporarily before and even after treatment because they face the traumatic situation and see the death closely or relish the meal when they get back to normality. Patients become reluctant, doubtful, angry, exhausted, regretted in stress. Therefore, they need support with greater zeal.

\subsection{Behavioral economics}

The economy is also affected by the various behaviors/psychological reactions of different stakeholders through high/low demand and high/low supply shocks and other reasons. For example: The investment decision of investors in fluctuating certain/uncertain conditions, by the consumer behavior in varying situations such as high/low-risk taking, healthy/unhealthy conditions, fear of injury, infection, fear of death, fear of loss, due to precaution, government instructions, quarantine, lockdown, curfew and other various reasons. In the www.astesj.com result, demand curtails and suppliers also hold the production according to limitations in orders and apply wait and watch policy. Labor force is prone to be infected with such pandemic diseases. The contagious disease affects labor from many aspects, e.g. infections, disability and deaths. Therefore, from the human resource side the production process slows down and employment rate reduces, hence supply curtails. Every economic indicator becomes vulnerable.

During the attack of COVID-19 hand washing, hygiene, diet, clean environment, mask and gloves wearing is projected. Likewise, by changing behavior, goods and services change. Manufacturing takes place in that connection.

On the other hand, people in quarantine can save much living cost, no social interaction/ gathering, no tour or outing cost, no hotel, restaurant, travel, parlor and theatre/cinema cost, overall precautionary steps to reduce the viral effect too. As [24] expresses the quarantining period is social isolation and disintegrate from the period, which results in the social pressure and psychological down. Similarly, [25] state that undertaking hygiene measures are not a big deal because it minimizes the possibility of contagion, which is very favorable for healthy economic and social conditions.

From the experience of these cruel epidemics, if the world population adopts some hygiene based behaviors and make them their habit to keep themselves safe and secure would reduce the transmissions and decrease the economic cost. Likewise, [26] emphasize the habit formation for desirable behaviors during the pandemic outbreaks. Subsequently, these behaviors offset the cost of contagious outbreaks exerting positive health effects and decrease the risk of viruses like COVID-19. Contagious diseases and behavioral economics have progressed recently for developing the change in behavior and understanding the nature of outbreaks. Scientists and policy makers can coordinate between the two approaches which can lead to reducing the speed of transmission of contagious and overall loss [27].

\section{Pakistan economic shock}

Pakistan being a developing country is already suffering from multiple socioeconomic problems. The outbreak of COVID-19 has dragged the poor country into more multifarious issues, to deal with.

Unfortunately, like global stock markets, freaking out Pakistan stock exchange faces curbing of the investment and production. The decrease in employment/ labor force is hitting the capital formation and production badly. Lockdown and restricted movement are disturbing channelization of raw material and finished goods. Plunging demand and sapping supply due to lock down and transportation restrictions has created a gap between suppliers and consumers. Limited movement of agricultural and industrial goods (raw material and finished goods) and nominal exploitation or uses of natural resources are increasing problem by narrowing economic activities. It also has slowed down the Investment process. This situation is responsible for the lower performance of the economy as a whole which leads to upsurge overall poverty This growing gap in the economy has created a big challenge for developing countries like Pakistan around the world.

Furthermore, Pakistan's economy is crumbling because of overall system shut down. For example, reduction in capital formation, production, revenue, trade imbalance and the health 


\section{N.K. Katper et al. / Advances in Science, Technology and Engineering Systems Journal Vol. 5, No. 4, 645-654 (2020)}

care, safety due to COVID-19 related extra medical expenditure has further burdened limited resources of the crippling economy of the country. Pakistan can face the estimated economic loss of Rs1.3tr initially due to coronavirus according to the news report. However, in this current situation, Pakistan may take some advantage of the lower oil prices dropped worldwide.

However, she would face the adverse impact of lower exports and necessary imports/tariffs. Lower imports would lead to scarcity of goods. Because unlike China and America or any other developed country, Pakistan is unable to manufacture all products locally. America and other developed countries are trying to produce goods locally but no poor country is at this level of economic strength.

Consistently, the news Pakistan reports that "we cannot afford to practice such lockouts given that we can face a massive revenue shortfall as our resources are limited and the economy is collapsing. The FBR estimates show that the lockdown of Karachi is going to cause major revenue losses which, if persisted till June 2020, then the tax losses would go up to Rs 380 billion". Equally, according to the present federal secretary commerce "the exports might face loss in the range of $\$ 2$ to $\$ 4$ billion as export orders had got cancelled. Pakistan's textile export sector relies on China for the bulk of its capital goods inputs, so there will be an impact if there is a protracted closedown of the Chinese economy. The imports would be reduced in the shape of declining POL prices as well as in quantity. Pakistan imported 80 billion barrels of POL products and keeping in view the low-ever prices in the international market in the last two decades, the import bill would shrink harming the FBR's collection and petroleum levy might also be reduced if the consumption decreased because of the possible lockdown in different parts of the country".

Therefore, a complete lockdown situation may not be in favor of Pakistan. Pakistan being a poor country does not afford complete shutdown. The worrisome situation is $70 \%$ of the population depends on agriculture or earning by working on the sites. Moreover, the Pakistan economy is too weak to bear the burden arising in the result of stagnating and no production. Pakistan can lose from multi spheres what contributes to the GDP. For example, Pakistan's GDP growth in 2017-18 was recorded as $5.5 \%$, in $2018-19$ was $1.9 \%$, in 2019 to the first quarter of 2020 was $-2.6 \%$ and in 2020 till the first quarter of 2021 is reported as $-0.2 \%$. We can notice a visible decline in GDP by these statistics. According to the estimation of the Planning Commission, the level of Pakistan GDP is Rs. 44trillion and $1 / 4^{\text {th }}$ stood at the amount of Rs. 11 trillion. Thus the loss by the outbreak of COVID-19 is predicted to occur at least $10 \%$ means Rs 1.1 trillion in the last Q of April-June. Some common macroeconomic indicators are given below with the comparison of the two years 2019 and 2020.

Furthermore, in Pakistan, the decreasing interest rate can play a role in lifting exports and other businesses. Still, it is criticized by economists that interest rates are not decreased at a satisfactory level. The interest rate has been decreased by $11 \%$, according to the situation through the monetary policy of SBP. This is also a fact that the inflation rate in Pakistan has fluctuated widely over the years since 1984 and onwards (see appendix A). Nonetheless, this time as compared to 2019 which is $7.74 \%$ reached at $13.25 \%$ in 2020 at that level of worry indicating the surging of prices more in the future along with a loss of labor especially daily wages and poor people working at lower levels. The increasing prices of routine products like sugar and wheat have created many problems for the lower and middle class to cope with the situation. Realizing the sensitivity of the time, producers in Pakistan must stop hoarding edible products in such critical time to let feed poor cheaply.Otherwise, all this leads to the short supply and rising inflation even more thus people may face starving at a greater level.To understand this reality a figure provided by SBP highlights the inflation rates of Pakistan in the global context (See the appendix B).

Table 2 Economic indicators of Pakistan

\begin{tabular}{|l|l|l|}
\hline $\begin{array}{l}\text { Economic indicators of } \\
\text { Pakistan }\end{array}$ & $\mathbf{2 0 1 8 - 1 9}$ & $\mathbf{2 0 1 9 - 2 0}$ \\
\hline GDP growth & $1.9 \%$ & $-2.6 \%$ \\
\hline GDP per capita & $\begin{array}{l}\$ 1,482 \\
\text { (nominal) }\end{array}$ & $\begin{array}{l}\$ 1,244 \\
\text { (nominal) }\end{array}$ \\
\hline Inflation rate & $6.74 \%$ & $11.12 \%$ \\
\hline Interest rate & $\begin{array}{l}12.25 \% \text { as } \\
\text { of June-19 }\end{array}$ & $\begin{array}{l}13.25 \% \\
7.00 \%\end{array}$ \\
\hline Exchange rate USD & PKR 160.00 & PKR 167.40 \\
\hline Unemployment rate & $4.45 \%$ & $6.2 \%$ \\
\hline Poverty rate & $29.5 \%$ & $\begin{array}{l}40.0 \% \\
\text { forecasted }\end{array}$ \\
\hline
\end{tabular}

How could poor and emerging economies be in the current scenario of the COVID-19 viral shock? Which has put even developed countries in greater trouble. Hence, the economy of Pakistan is not self-sufficient to deal with it without intensifying losses. If we compare Pakistan with the pandemic host country China and other regional countries, we can analyze much difference. China is the biggest economy and thus could do what they needed. Despite that, they face an economic loss substantially. Currently, China has started reviving her economy. Chinese factories are working and manufacturing the medical equipment for local and international market supply. Through producing and providing medical equipment and supplying widely to various countries in the world China is creating and reviving jobs too. Contrariwise Pakistan's economy is more delicate to bear a huge loss. Pakistan is not self-sufficient economically therefore badly affected in terms of GDP, GNP, production, employment and per capita income. Consequently, the common man is living a miserable life and poverty increased badly. Besides, in Pakistan, most of the illiterate and unaware population does not understand the situation properly, they are afraid of everything even from quarantine and treatment. Though many of the infected people reacted wisely and recovered yet others lost their lives. The role of doctors and army/police is important many of front fighters in this regards lost their lives while providing treatment and dealing with infected crowds.

Similarly, COVID-19 outbreak drastically hit all over the Asian region. The manufacturing, service and trade activities are badly affected in the Asian region, including Pakistan The disturbing trade led to exchange rate depreciation. Inflation along with demand and supply shocks in the whole region is alarming.

\footnotetext{
${ }^{2}$ Malik A. Rehman. (2020, March 26) Pak economy under dark shadow of coronavirus vs deep economic crisis. The News Intenrnational. 


\section{N.K. Katper et al. / Advances in Science, Technology and Engineering Systems Journal Vol. 5, No. 4, 645-654 (2020)}

The epidemic has distressed financial markets, especially capital markets (equity/bond markets) in the region. The drop in the stock exchanges in the whole region is exerting an adverse effect on the regional economic indicators (See appendix c).

\section{Conclusion}

In this paper, we discussed the outbreak of pandemic COVID-19 and its effects on the global economy as well as the Pakistan economy. We evaluate that along with the strong demographic losses of the contagious virus, the economic losses are also jeopardizing the world in its full capacity. We can judge the channel of globalization as the source of spreading any good or bad worldwide. The blessings of globalization in the shape of trade, business, employment, education, tourism and socialization we have been shared since long. However, we cannot avoid the curses of globalization in the shape of contagious, diseases and other disasters too. For example, the world witnessed the historical contagious diseases time to time in the past and this time the widespread of novel coronavirus is also the result of globalization. Thus, we can conclude that the greater the extent to which the world is becoming a global village by increasing mobilization means and ways the higher the blessing or curses are shared around the globe. We analyzed the multidimensional economic shocks worldwide. For example Demographic hits, socio-psychological hit and Economic hits from the revenue and expenditure side as well as demand and supply side. We also discuss how behavioral economies are important in the result of changing behaviors of people. Almost all the countries are observing losses in their business activities and every sector of industries tumbling in their revenue. Capital markets are shrinking their activities. The stock markets/ equity markets got hard hit so declining their performance around the globe. Apart from that, we elaborate that developing countries like Pakistan are suffering more from the repercussions of a cruel pandemic that poverty is getting even more strength. The process of economic development weakens further by the deteriorating performance of all socioeconomic indicators. We conclude that the Governments, policy makers and stakeholders along with realization must take soothing measures to uplift the dropped down economy and try to support markets with high/low supply and high/low demand creating imbalances from both sides of demand and supply in markets for different commodities.

\subsection{Recommendations}

In this critical time, the role of Government is very important to fight the battle against the microscopic enemy. [28], describes that the intensity of financial loses will be a responsibility of governments to control.

Government's expenditure on health care is inevitable to control the transmission and treatment of infected people. Government and the public must work hard and go together in this fight by moving forward and think of each other collectively and do not leave anyone behind.

The government may compromise for the production of luxury goods but the core sectors, which relates to basic needs, i.e. utility services, food, health and construction should not be compromised by the total lockdown. However, in the operating factories, applying SOPs is essential to provide health care.
Moreover, by deploying the teams of doctors to check employees frequently will ensure smooth sailing during these troubled times. Significant Business organizations should be given relaxation on their fixed costs, inject liquidity, where ever needed to sustain the pressure of abrupt breakout and sudden downfall.

Isolation centers and temporary hospitals should be created in sufficient number. According to the situation, retired doctors may be called in case of need.Increase the doctors and nurses by calling final- year-medical students and house jobholders. Meanwhile, foreign degree holders may be called by waving their PMDC exams. Special training may be given to new nurses and doctors.Sufficient stock of medical kits, uniforms of doctors and patients, ventilators, drugs and other clinical apparatus should be arranged.

Support the labour force and daily wages people who lost their jobs or income and health. They may be compensated through government by free treatment and distribution of food/groceries where necessary.

Extraordinary cleaning programs should be started. More importantly, behavioural change, social attitude, values, norms, and changing lifestyle is highly required in Pakistan. More and frequent awareness programs are needed and teams may be organized for public awareness.

Spend a handsome amount for research and development to improve scientific research and preparing vaccine and medicine and/or other necessary equipment against the contagious virus. Create multiple teams for this highly demanding cause and make plans to work hard to face the crises efficiently.

The government may take measures to protect the people residing in foreign countries by providing support to them and make sure of their safety by the country's embassies.

Many foreign returned people are unknowingly scattered in different regions of the country and they are mixed up with masses thus unnoticed. Government and pubic try their best together to detect and testify them and their connected circle to reduce transmissions.

The government may review fiscal and monetary policies frequently, according to the situation.

Compliance with Ethical Standards:

It is to confirm that principles of ethical and professional conduct have been carefully followed and the following statements are to ensure the mandatory requirements of the journal.

a. Funding: It is to mention here that there is no sponsorship received from any institution nor any institution is requested for the funding.

b. Ethical approval:The Editors reserve the right to reject manuscripts that do not comply with the above-mentioned guidelines. The author will be held responsible for false statements or failure to fulfil the above-mentioned guidelines.

c. Informed consent: It is to ensure here that the research work does not involve human participation nor research on animals is involved.

d. Conflict of the statement: On behalf of all authors, the corresponding author states that there is no conflict of interest involved, neither financial nor non-financial.

\section{Conflict of Interest}

The authors declare no conflict of interest. 


\section{Acknowledgment}

Authors are thankful to the editor ASTES, its team to correspond and guide properly, many thanks to the anonymous reviewers for their productive feedback.

\section{References}

[1] W. J. Mckibbin, R Fernando, "The global macroeconomic impacts of COVID-19: Seven scenarios", 2020. http://dx.doi.org/10.2139/ssrn.3547729

[2] J. T. Cuddington, J D Hancock, "Assessing the Impact of AIDS on the Growth Path of the Malawian Economy" Journal of Development Economics 43(2), 363-68, 1994. $\quad$ https://doi.org/10.1016/03043878(94)90013-2

[3] J. T. Cuddington, J D Hancock, "A Dynamic Aggregate Model of the AIDS Epidemic with Possible Policy Interventions" Journal of Policy Modeling 16(5), 473-96, 1994. https://doi.org/10.1016/0161-8938(94)90024-8

[4] A. Deaton, "Health in an Age of Globalization" (No. w10669). National Bureau of Economic Research, 2004. 10.3386/w10669

[5] O. Kodila-Tedika, S. A. Asongu, J. M. Kayembe, "Middle class in Africa: Determinants and consequences" International Economic Journal, 30(4), 527-549, 2016. https://doi.org/10.1080/10168737.2016.1204340

[6] T. Ensor, S. Cooper, L. Davidson, A. Fitzmaurice, W. J. Graham, "The impact of economic recession on maternal and infant mortality: lessons from history" BMC Public Health, 10(1), 727, 2010. https://doi.org/10.1186/1471-2458-10-727

[7] T. Ensor, S. Cooper, "Overcoming barriers to health service access: influencing the demand side" Health policy and planning, 19(2), 69-79, 2004. https://doi.org/10.1093/heapol/czh009

[8] D. A. Robalino, A. Voetberg, "The Macroeconomic Impacts of AIDS in Kenya Estimating Optimal Reduction Targets for the HIV/AIDS Incidence Rate" Journal of Policy Modeling 24(2), 195-218, 2002. https://doi.org/10.1016/S0161-8938(02)00097-2

[9] N. Ruggiano, T. E. Perry, "Conducting secondary analysis of qualitative data: Should we, can we, and how?" Qualitative Social Work, 18(1), 81-97, 2019. https://doi.org/10.1177\%2F1473325017700701

[10] D. A. Robalino, A. Voetberg, "The Macroeconomic Impacts of AIDS in Kenya Estimating Optimal Reduction Targets for the HIV/AIDS Incidence Rate". Journal of Policy Modeling 24(2), 195-218, 2002. https://doi.org/10.1016/S0161-8938(02)00097-2

[11] D. tuckler, L. P. King, S. Basu, "International Monetary Fund programs and tuberculosis outcomes in post-communist countries" PLoS Med, 5(7), e143, 2008. https://doi.org/10.1371/journal.pmed.0050143

[12] J. Chou, N. F. Kuo, S. L. Peng, "Potential impacts of the SARS outbreak on Taiwan's economy". Asian Economic Papers, 3(1), 84-99, 2004. https://doi.org/10.1162/1535351041747969

[13] W. Hai, Z. Zhao, "The Short-Term Impact of SARS on the Chinese Economy" Asian Economic Papers 3(1), 57-61, 2004. https://doi.org/10.1162/1535351041747905

[14] A. Sui, Y. C. R., Wong, "Economic Impact of SARS: The Case of HongKong", Asian Economic Papers 3(1), 62-83, 2004. https://doi.org/10.1162/1535351041747996

[15] C. Binder, "Coronavirus fears and macroeconomic expectations", Review of Economics and Statistics, 1-27, 2020. https://doi.org/10.1162/rest a 00931

[16] J. L. Kulzer, J. A. Penner, R. Marima, P. Oyaro, A. O. Oyanga, S. B. Shade, E. A. Bukusi, "Family model of HIV care and treatment: a retrospective study in Kenya" Journal of the International AIDS Society, 15(1), 8-8. 2012. https://doi.org/10.1186/1758-2652-15-8

[17] R. Keith, Z. Lin, "SARS in Chinese politics and law" China Information, 21(3), 403-424, 2007. https://doi.org/10.1177\%2F0920203X07083321

[18] J. Barry, Supply chain risk in an uncertain global supply chain environment international journal of physical distribution \& logistics management 34(9), 695-697, 2004. DOI 10.1108/09600030410567469

[19] W. J. Mckibbin, R. Fernando, "The global macroeconomic impacts of COVID-19: Seven scenarios", 2020. http://dx.doi.org/10.2139/ssm.3547729

[20] N. Ruggiano, T. E. Perry, "Conducting secondary analysis of qualitative data: Should we, can we, and how?" Qualitative Social Work, 18(1), 81-97, 2019. https://doi.org/10.1177\%2F1473325017700701

[21] W. J. Mckibbin R. Fernando, The global macroeconomic impacts of COVID-19: Seven scenarios, 2020. http://dx.doi.org/10.2139/ssrn.3547729

[22] L. Boone, J. Dewulf, G. Ruysschaert, T. D’Hose, H. Muylle, I. Roldán-Ruiz, "Assessing the consequences of policy measures on long-term agricultural productivity-Quantification for Flanders" Journal of Cleaner
Production, 246

119000

2020 https://doi.org/10.1016/j.jclepro.2019.119000

[23] X. Zhang, J. Xie, R. Rao, Y. Liang, "Policy incentives for the adoption of electric vehicles across countries", Sustainability, 6(11), 8056-8078, 2014. https://doi.org/10.3390/su6118056

[24] S. S. SyraMadadMadad, J. Masci, S. N. V. Cagliuso, M. Allen, "Preparedness for zika virus disease-New York city, 2016" Morbidity and Mortality Weekly Report, 65(42), 1161-1165, 2016. doi:10.2307/24859111

[25] K. C. Hyams, F. M. Murphy, "Responding to Chemical, Biological, or Nuclear Terrorism: The Indirect and Long-Term Health Effects May Present the Greatest Challenge" Journal of Health Politics, Policy and Law 27(2), 273-91, 2002. https://doi.org/10.1215/03616878-27-2-273

[26] W. J. Mckibbin, R. Fernando, "The global macroeconomic impacts of COVID-19: Seven scenarios", 2020. http://dx.doi.org/10.2139/ssrn.3547729

[27] W. J. McKibbin, R. Fernando,. "The global macroeconomic impacts of COVID-19: Seven scenarios", 2020. http://dx.doi.org/10.2139/ssrn.3547729

[28] R. Hussam, A., Rabbani, G. Reggiani, N. Rigol, " Habit formation and rational addiction: A field experiment in handwashing", Harvard Business School BGIE Unit Working Paper, 18-030, 2017. http://dx.doi.org/10.2139/ssrn.3040729 


\section{Appendices}

Appendix A Pakistan's inflation 1984-2021

Pakistan: Inflation rate from 1984 to 2021

(compared to the previous year)

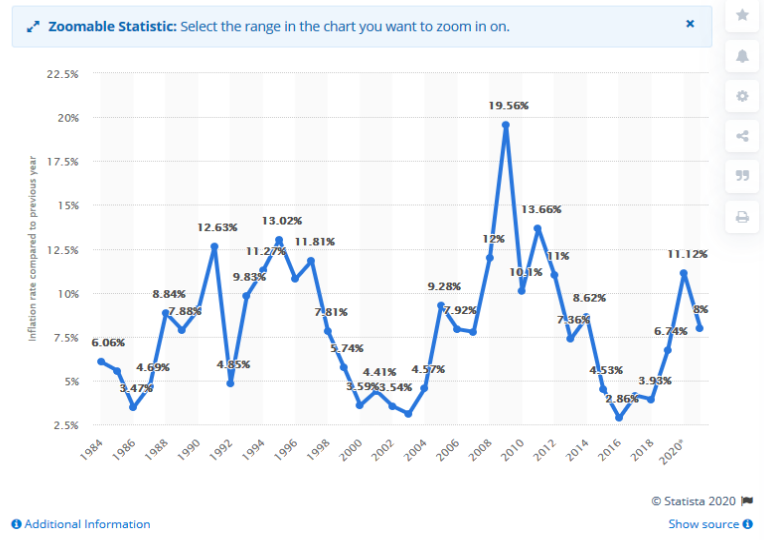

Appendix B: Pakistan's Inflation to the global context

State Bank of Pakistan

\section{Inflation in Global Context}

In global context, Pakistan witnessed highest inflation not only in comparison with developed economies but also with emerging economies (See figure 10.1).

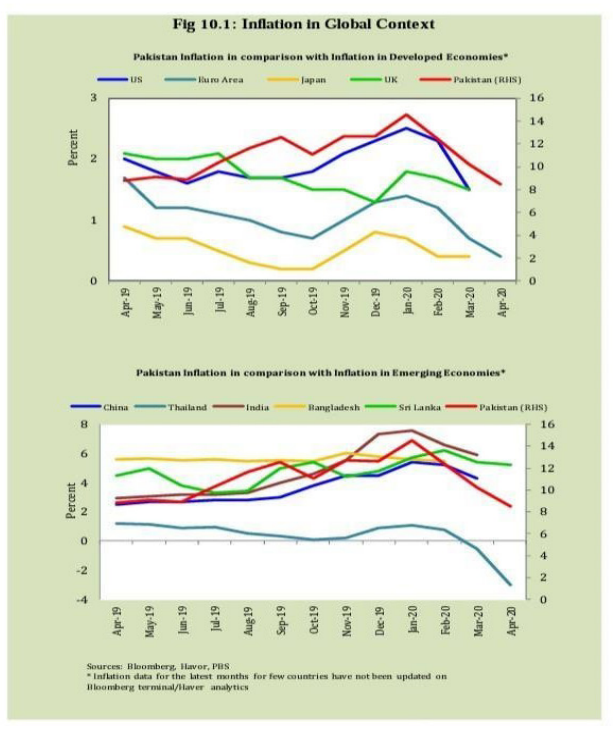

Appendix C:
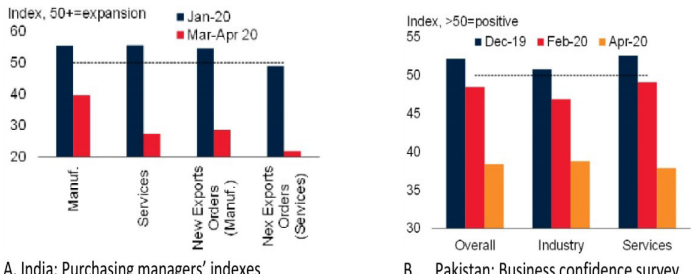

A. India: Purchasing managers' indexes

B. Pakistan: Business confidence survey
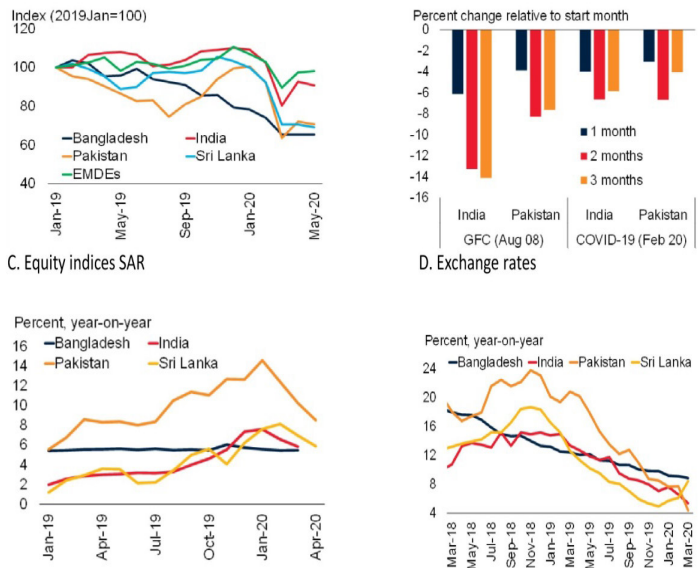

E. Inflation

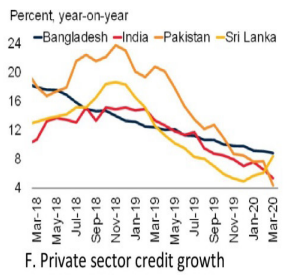

